\title{
The Correlation Between Purine Intake And Blood Uric Acid Level In Postmenopausal Women In The Working Area Of Puskesmas II East Denpasar
}

\author{
Putu Indah Budi Apsari ${ }^{1}$, I Made Maha Prasetya ${ }^{1}$, Putu Sutisna ${ }^{{ }^{*}}$ \\ ${ }^{1}$ Faculty of Medicine and Health Sciences, Universitas Warmadewa University \\ *psutisna@yahoo.com
}

\begin{abstract}
Hyperuricemia is a condition of elevated blood uric acid level above normal value. One of the risk factors that causes hyperuricemia is high purine intake. Balinese generally consume foods that contain high purine, such as pork lawar, chicken betutu and other foods that potentially increase blood uric acid level. This study aimed to assess the relation between purine intake and blood uric acid level in postmenopausal women in the working area of Puskesmas II East Denpasar. This cross-sectional study used 100 postmenopausal women as respondents. Daily purine intake were counted by semiquantitative food frequency questionnaires. The results showed that mean of purine daily intake was $408.72 \pm 153.50 \mathrm{mg} /$ day. The proportion of respondents who consumed purine more than $500 \mathrm{mg} /$ day was $34 \%$, intake purine less than $500 \mathrm{mg} / \mathrm{day}$ was $66 \%$. Levels of blood uric acid in respondents were in the range of $2.6-8.4 \mathrm{mg} / \mathrm{dL}$ and the average was $5.52 \pm 1.661 \mathrm{mg} / \mathrm{dL}$. Purine intake had the strongest effect on blood uric acid level ( $p=0,019 ; \mathrm{OR}=3,198 ; 95 \% \mathrm{CI}=1,208-8,461)$. It is recomended in order to prevent hyperuricemia, the community should be advised to reduce consumption of high purine foods.

Keyword : Correlation, Postmenopausal, East Denpasar.
\end{abstract}

\section{Introduction}

Hyperuricemia is defined as an increase in blood uric acid levels above normal that occurs due to excessive uric acid production, reduced uric acid excretion or a combination of both.[1,2] Hyperuricemia is determined if blood uric acid levels are $>7 \mathrm{mg} / \mathrm{dL}$ in men and $>6$ $\mathrm{mg} / \mathrm{dL}$ in women. [3,4] The prevalence of hyperuricemia in the United States in 2007-2008 was $21.4 \%$, with the prevalence of women higher than men.[5] Previous studies in China have found the prevalence of hyperuricemia in women increases with age. This is influenced by a decrease in estrogen production in women after menopause, which in turn has an impact on increased blood uric acid levels.[6] Intake of high purine foods is one of the risk factors for hyperuricemia, therefore someone with hyperuricemia is advised to avoid high purine food intake. Nonetheless, there is still confusion in the dietary relationship with uric acid levels, resulting in differences in dietary recommendations for patients with hyperuricemia. [7]

Food consumption patterns of Balinese people are generally in the form of processed foods containing high purines such as pork lawar, chicken betutu, chicken or pork steam, pork satay and grill pork which have the potential to increase uric acid levels and lead to hyperuricemia.[8] The study by Indrawan (2005) found the prevalence of hyperuricemia in Denpasar City at $18.2 \%$. [9] Another study conducted by Diana (2007) found the prevalence of hyperuricemia in the Nusa Ceningan community at $17 \%$.[10] Studies on the relationship 
between intake of purine and blood uric acid levels have been carried out in Bali, but as far as the researchers know, similar studies with postmenopausal female respondents have never been conducted in Denpasar City. Therefore, researchers are interested in knowing the relationship between intake of purine and blood uric acid levels in postmenopausal women. The results of this study are expected to provide information to the public regarding the relationship between purine intake and blood uric acid levels, so prevention of the occurrence of hyperuricemia can be done early.

\section{Method}

\subsection{Research design}

This study used an observational analytical method with a cross-sectional approach to assess the relationship between purine intake and blood uric acid levels in postmenopausal women in the work area of Puskesmas II East Denpasar. This research was conducted in Banjar Semaga and Banjar Tembau Kaja, Penatih Village, East Denpasar District. Research location was selected by multistage random sampling. This research took place in September until December 2017. Total 100 women aged 50-65 years who were domiciled in Banjar Semaga and Banjar Tembau Kaja were recruited as samples of the study that selected by simple random sampling. The inclusion criteria were postmenopausal women $(>1$ year amenorrhoea) aged 50-65 years, domiciled in Banjar Semaga and Banjar Tembau Kaja, capable to communicate well and are willing to take part in research by giving informed consent.

\subsection{Data Collection}

According to the literature, beside of purine intake there were several other factors such as BMI, hypertension and a history of kidney disease associated with hyperuricemia.[11,12] Therefore, the three variables mentioned above were included as confounding variables in this study. The demographic characteristics of the respondents were obtained from data at the Penatih Village Office. Daily purine intake of subjects was obtained through semi-quantitative food frequency questionnaire with one month recall. Data about types, portions in one meal and frequency of consumption of certain foods that have been consumed by respondents in the past month. The average amount of daily purine intake was counted from a food ingredient. Each average intake of purine from a food was added to obtain the total daily purine intake of the respondent. The respondent's BMI was measured by dividing the body weight $(\mathrm{kg})$ by the square of the respondent's height (meters). The results of the calculation were adjusted according to WHO's BMI classification for the Asian Pacific region [13]. Respondents in this study categorized into hypertension groups were respondents with one or more of the following criteria: having a history of hypertension, having a systolic blood pressure above $140 \mathrm{mmHg}$ or diastolic blood pressure $90 \mathrm{mmHg}$.[14] Blood pressure measurement is carried out after the respondent has rested for at least 10 minutes. Blood pressure was measured by mercury sphygmomanometer twice, ie before and at the end of the interview session. Information about the history of kidney disease was obtained through direct interviews with respondents. The uric acid level of the respondent's blood was measured with uric acid glucometer and expressed in units of $\mathrm{mg} / \mathrm{dL}$.

\subsection{Data analysis}


The data was processed and analyzed by using SPSS. Data analysis was carried out through three stages, namely univariate, bivariate and multivariate analysis. Univariate analysis was performed to determine the distribution and frequency of respondents' demographic data (age of respondents, age at menopause and menopause) and variable intake of purine, BMI, hypertension, history of kidney disease and blood uric acid levels. Bivariate analysis was performed to determine the relationship between independent variables and dependent variables and control through analysis of confounding variables. The statistical test carried out in bivariate analysis was the chi square test at significance level $\mathrm{p}<0.05$. Multivariate analysis in this study was conducted to compare the effects of independent variables and confounding variables on dependent variables. The statistical test carried out in mutivariate analysis within logistic regression test by Enter method. Variables that included in the logistic regression test were variables that have value of $\mathrm{p}<0.05$.

\section{Results And Discussion}

The result showed mean of respondents age was 56.37 years. Most respondents experienced menopause when they were 51 years old during 2-16 years. The mean daily purine intake of respondents was $408.72 \pm 153.50 \mathrm{mg} /$ day with the highest level 708.47 $\mathrm{mg} /$ day. The mean of body mass index was $25.32 \pm 3.280 \mathrm{~kg} / \mathrm{m} 2$, the highest uric acid level of respondents was $8.4 \mathrm{mg} / \mathrm{dL}$, with an average of $5.52 \pm 1.661 \mathrm{mg} / \mathrm{dL}$. In this study there were no respondents who had a history of kidney disease, therefore the variable history of kidney disease was not included in the data analysis (Table1).

Table 1. Characteristics of The Study subjects

\begin{tabular}{llll}
\hline \multicolumn{1}{c}{ Characteristic of subject } & \multicolumn{1}{c}{ Minimum } & Maximum & \multicolumn{1}{c}{ Mean \pm SD } \\
\hline Age (years) & 50 & 65 & $56,37 \pm 4,136$ \\
Menopausal age (years) & 47 & 55 & $50,55 \pm 1,623$ \\
Duration of menopause (years) & 2 & 16 & $5,82 \pm 3,852$ \\
Purin intake (mg/day) & 142,48 & 708,47 & $408,72 \pm 153,50$ \\
BMI (kg/m2) & 17,58 & 32,07 & $25,32 \pm 3,280$ \\
Blood uric acid level (mg/dL) & 2,6 & 8,4 & $5,52 \pm 1,661$ \\
\hline
\end{tabular}

Table 2. Multivariate analyzis of factors influencing hyperuricemia

\begin{tabular}{lclccc}
\hline \multicolumn{1}{c}{ Variabel } & $\begin{array}{c}\text { Hyperuricemia } \\
(\mathbf{n \%})\end{array}$ & $\begin{array}{c}\text { Normouricemia } \\
(\mathbf{n \%})\end{array}$ & OR & CI 95\% & p \\
\hline $\begin{array}{l}\text { Purine daily intake (mg) } \\
\text { Moderate }(>500)\end{array}$ & $23(67,6 \%)$ & $11(32,4 \%)$ & 4,182 & $1,731-10,103$ & 0,001 \\
Low $(<500)$ & $22(33,3 \%)$ & $44(66,7 \%)$ & & & \\
BMI (kg/m2) & $31(54,4 \%)$ & $26(45,6 \%)$ & 2,470 & $1,084-5,629$ & 0,030 \\
Obese (>25) & $14(32,6 \%)$ & $29(67,4 \%)$ & & & \\
$\begin{array}{l}\text { Not Obese }(<25) \\
\text { Hypertension }\end{array}$ & $34(54,8 \%)$ & $28(45,2 \%)$ & 2,981 & $1,260-7,052$ & 0,012 \\
Yes & $11(28,9 \%)$ & $27(71,1 \%)$ & & & \\
No & & & & \\
\hline
\end{tabular}


The results of bivariate analysis showed purine intake $(\mathrm{p}=0.001 ; \mathrm{OR}=4.182 ; 95 \% \mathrm{CI}=$ 1.731-10.103), BMI ( $\mathrm{p}=0.03$; OR $=2,470 ; 95 \% \mathrm{CI}=1,084-5,629)$ and hypertension $(\mathrm{p}=0$. 012 ; OR $=2.981 ;$ CI $95 \%=1,260-7,052$ ) has a significant relationship with blood uric acid levels (Table 2). Variables of purine intake, BMI and hypertension were then analyzed simultaneously with the logistic regression test. Based on the results of multivariate analysis, purine and hypertension intake was a risk factor for hyperuricemia $(p<0.05)$. Whereas BMI was not associated with hyperuricemia ( $p>0.05$ ). Logistic regression test results showed that purine intake had a greater relationship strength $(\mathrm{OR}=3.198 ; 95 \% \mathrm{CI}=1.208-8,461)$ compared to hypertension $(\mathrm{OR}=1.52195 \% \mathrm{CI}=1.043-6,347)$ to blood uric acid levels. (Table 3).

Table 3. Relationship between Purine Intake, Body Mass Index and Hypertension with Blood Uric Acid Levels

\begin{tabular}{lcr}
\hline \multicolumn{1}{c}{ Variable } & $\boldsymbol{p}$ & OR (CI 95\%) \\
\hline Purine intake (medium / low) intake & 0,019 & $3,198(1,208-8,461)$ \\
Body mass index (obese / not obese) & 0,378 & $1,521(0,598-3,866)$ \\
Hypertension (Yes / no) & 0,040 & $2,573(1,043-6,347)$ \\
\hline
\end{tabular}

The average purine intake consumed by respondents in this study was $408.72 \pm 153.50 \mathrm{mg}$ / day. The previous two studies obtained the average purine intake of the residents of Ubud and Nusa Ceningan, respectively at $153.37 \pm 77.83 \mathrm{mg} /$ day and $245.65 \pm 76.52 \mathrm{mg} /$ day.[8,10] The difference was assumed by researchers to be influenced by geographical location and variation of food in each region. Ubud and Nusa Ceningan are rural (rural) areas that have fewer residents than Denpasar, which is an urban (urban) area. The size of the population will have an impact on the level of supply and access to food. Changes in the level of supply and access to food will affect the pattern and level of consumption of people in certain regions.[14] In line with this, Lisa et al. (2004) as quoted by Sholikah et al., (2017) state that food availability in the regions urbanization is higher than rural areas.[15] This may result in urban communities tend to consume more high-purine foods than rural people. This study found a significant association between purine intake and blood uric acid levels $(\mathrm{p}=$ $0.019 ; \mathrm{OR}=3.198 ; 95 \% \mathrm{CI}=1.208-8.461)$. These results showed that someone with moderate purine intake ( $>500 \mathrm{mg} /$ day) had a risk of 3,198 times higher hyperuricemia than someone with a low purine intake ( $<500 \mathrm{mg} /$ day) (Table 3 ). The results of this study are supported by the findings of Pursriningsih (2015) who found a very significant relationship between intake of purine and blood uric acid levels $(\mathrm{p}=0,000$, pearson correlation $=0.64)$. [16] Similar results were also found in the study conducted by Talarima (2012) which states that purine intake is one of the risk factors for hyperuricemia $(B=1,438 ; p=0,000 ; O R=4,214 ; 95 \% \mathrm{CI}=2,15$ 8,24).[17]

Purine intake into the human body is very difficult to remove, because most food contains purines. [18] Foods that contain nucleic acids, after ingestion will undergo a process of degradation in the intestine into nucleutides. The nucleutides formed can return to the absorption of the intestinal mucosa, or undergo further degradation into purine and ribose bases. [19] Nucleusides (adenosine and guanosine) from nucleutide degradation (AMP and GMP) then undergo catabolism through several reaction stages, with the final result gout.[20] The results of bivariate analysis showed that there was a significant relationship between BMI and blood uric acid levels $(\mathrm{p}=0.03)$ (Table 2). After a concurrent analysis of the purine and hypertension intake variables, the relationship between BMI and blood uric acid levels was not significant $(\mathrm{p}=0.378$; $\mathrm{OR}=1.521 ; 95 \% \mathrm{CI}=0.598-3.866)$ (Table 3$)$. Changes in the 
results obtained in multivariate analysis are likely due to two other variables (purine intake and hypertension) which have a stronger influence on blood uric acid levels. Different results were obtained in the study conducted by Wulandari \&Rahayuningsih (2015). The results of multivariate analysis in the study showed a significant association between BMI and blood uric acid levels ( $\mathrm{p}=0,009 ; \mathrm{OR}=3.157 ; 95 \% \mathrm{CI}=2,357-42,300)$. [20] The differences in the results obtained in this study and previous studies conducted by Wulandari \& Rahayuningsih (2015) may be influenced by differences in the BMI cut-off values and sampling techniques used. This study found a significant association between hypertension and uric acid levels ( $\mathrm{p}$ value $=0.040 ; \mathrm{OR}=2.573(95 \% \mathrm{CI}=1.043-6,347)$. Judging from the odds ratio, someone with hypertension had a risk of hyperuricemia 2,573 times higher than normal person. The findings was supported by the results of a cohort study conducted by McAdams-DeMarco et al (2013) in 8,342 respondents. The results of this study showed that there was a very significant relationship between hypertension and hyperuricemia $(\mathrm{p}=<0.001 ; \mathrm{RR}=1.65 ; 95 \% \mathrm{CI}=1.30$ 2.09). After six years of follow-up, 304 respondents experienced hyperuricemia and $40 \%$ of them were suffered hypertension The relationship between hypertension and hyperuricemia was influenced by the role of the kidneys. [17] Most uric acid excretion was done through the kidneys. [21] Complications of hypertension such as glomerular arteriolar injury and glomerulosclerosis could cause damage to the kidneys which will reduce uric acid excretion into urin.

\section{Conclusions}

Purine intake has a significant relationship and the strongest influence on blood uric acid levels compared to hypertension.The study also found that BMI was not associated with blood uric acid levels. People, especially postmenopausal women, are expected to be able to adopt a healthy lifestyle to prevent the occurrence of hyperuricemia, especially by reducing the intake of high purine foods.

\section{References}

[1] Putra TR. Hiperurisemia. 2011. In: Setiawati S, Alwi I, Sudoyo AW, Marcellus S, Setiyohadi B, Syam AF, editors. Buku ajar ilmu penyakit dalam. 6th ed. Jakarta: Interna Publishing.

[2] De Oliveira EP, Burini RC. High plasma uric acid concentration: causes and consequences. Diabetology \& Metabolic Syndrome. 2012; 4(1): 12-8.

[3] Jin M, Yang F, Yang I, Yin Y, Luo JJ, Wang H, Yang XF. 2012 Uric acid, hyperuricemia and vascular diseases. Frontiers in Bioscience: A Journal and Virtual Library. 17: 656-69.

[4] Maiuolo J, Oppedisano F, Gratteri S, Muscoli C, Mollace V. 2016. Regulation of uric acid metabolism and excretion. International Journal of Cardiology. Vol 213: 8-14.

[5] Zhu Y, Pandya BJ, Choi HK. 2011. Prevalence of gout and hyperuricemia in the US general population: The National Health and Nutrition Examination Survey 2007-2008. Arthritis \& Rheumatism. 63(10): 3136-41.

[6] Qiu L, Cheng XQ, Wu J, Liu JT, Xu T, Ding HT, Liu YH, Ge ZM, Wang YJ, Han HJ. 2013. Prevalence of hyperuricemia and its related risk factors in healthy adults from Northern and Northeastern Chinese Provinces. BMC Public Health. 13(1): 664-72.

[7] Zgaga L, Theodoratou E, Kyle J, Farrington SM, Agakov F, Tenesa A, Walker M, Mcneill G, Wright AF, Rudan I. 2012. The association of dietary intake of purine-rich vegetables, 
sugarsweetened beverages and dairy with plasma urate, in a cross-sectional study. Plos One. Vol 7(6).

[8] Putra TR. 2007. Hubungan konsumsi purin dengan hiperurisemia pada Suku Bali di daerah pariwisata pedesaan. Journal of Internal Medicine. Vol 8(1): 37-43.

[9] Indrawan IGNB. 2005. Hubungan konsumsi purin tinggi dengan hiperurisemia studi potong lintang analitik pada penduduk Suku Bali asli di Kota Denpasar [tesis]. Denpasar (Indonesia): Universitas Udayana.

[10] Diana W. 2007. Hubungan antara hipertensi dan hiperurisemia pada Suku Bali asli di Pulau Nusa Ceningan [tesis]. Denpasar (Indonesia): Universitas Udayana.

[11] Choi HK, Atkinson K, Karlson EW, Curhan G. 2005. Obesity, weight change, hypertension, diuretic use, and risk of gout in men: the health professionals follow-up study. Archives of Internal Medicine. Vol 165(7): 742-8.

[12] Mcadams-Demarco MA, Law A, Maynard JW, Coresh J, Baer AN. 2013. Risk factors for incident hyperuricemia during mid-adulthood in African American and white men and women enrolled in the ARIC cohort study. BMC Musculoskeletal Disorders. Vol 14: 347-54.

[13] World Health Organization Western Pacific Regio. 2000. International Association for the Study of Obesity, International Obesity Task Force. The Asia-Pacific perspective: redefining obesity and its treatment. World Health Organization. [cited 2017 Dec].

[14] Ariani M. 2010. Analisis konsumsi pangan tingkat masyarakat mendukung pencapaian diversifikasi pangan. Gizi Indonesia. Vol 33(1): 20-8.

[15] Sholikah AS, Rustiana ER, Yuniastuti A. 2017. Faktor-faktor yang berhubungan dengan status gizi balita di pedesaan dan perkotaan. Public Health Perspective Journal. Vol 2(1): 9-18.

[16] Pursriningsih SS. 2015. Hubungan asupan purin, vitamin c dan aktivitas fisik terhadap kadar asam urat pada remaja laki-laki [skripsi]. Semarang (Indonesia): Universitas Diponegoro.

[17] Talarima B, Amiruddin R, Arsin AA. Faktor risiko "gouty arthritis" di Kota Masohi Kabupaten Maluku Tengah tahun 2010. Makara Kesehatan. Vol 16(2): 89-94. 